\title{
Different Photosynthetic Responses of Black Cherry (Prunus serotina) with Different Sensitivities to Ambient Ozone Concentrations under Natural Conditions
}

\author{
Myoung-Hui Yun ${ }^{1 *}$ and Boris I. Chevone ${ }^{2}$ \\ ${ }^{1}$ Rice Research Div., National Institute of Crop Science, 151, Seodun-dong, \\ Gwonseon-gu, Suwon, Gyeonggi-do, Korea \\ ${ }^{2}$ Department of Plant Pathology, Physiology, and Weed Science, Virginia Tech, Blacksburg, VA, 24060
}

(Received November 12, 2008; Revised December 17, 2008; Accepted December 23, 2008)

\section{자연상태에서 대기 중 오존 농도에 상이한 민감성을 가진 Black Cherry(Prunus serotina)의 상이한 광합성 반응}

\author{
윤명희 ${ }^{1 *} \cdot$ Boris I. Chevone ${ }^{2}$ \\ 1농촌진흥청 국립식량과학원, ${ }^{2}$ 버지니아폴리테크닉 주립대학교 \\ (2008년 11월 12일 접수; 2008년 12월 17일 수정; 2008년 12월 23일 수락)
}

\begin{abstract}
Two different sensitivity classes of black cherry (Prunus serotina) under the natural growing environmental conditions were assessed adjacent to Air Monitoring Station located at Horton research center in Giles County, Virginia, USA. Ambient ozone concentrations, leaf gas exchange, and visible foliar injury were measured on-site during the growing seasons of 2000, 2001, and 2002. Ambient ozone exposures were sufficient to induce typical foliar visible injury corresponding with the reduction in photosynthetic activities only in sensitive black cherry. There were positive correlations between increasing cumulative ozone concentration and percent reduction in maximum net photosynthetic rates $\left(\mathrm{Pn}_{\mathrm{MAX}}\right)$ under saturating light conditions and in quantum yield for carbon reduction $\left(\Phi \mathrm{CO}_{2}\right)$ of sensitive black cherry compared to tolerant black cherry. There was a negative correlation between chlorophyll content and percent leaf injury in sensitive black cherry. Furthermore, $\mathrm{Pn}_{\mathrm{MAX}}$ was inversely related to percent leaf injury.
\end{abstract}

Key words : Photosynthetic activity, Ozone, Sensitivity, Black Cherry

\section{Introduction}

Ozone is considered as one of the most widespread and serious air pollutants affecting forest trees (Simini et al., 1992; Skelly, 2000). Ozone enters leaf through stomata, diffuses and reacts with the cellular membrane, and enters into metabolic processes (Reich, 1987). Therefore, ozone induced injury is closely related to physiological impairments with/without visi- ble foliar injury. Samuelson (1994) reported the reduced photosynthetic rates and stomatal conductance accompanied with visible foliar injury when exposed to ambient ozone concentration.

Black cherry (Prunus serotina) is an economically and ecologically important in eastern forest of the United States (Rebbeck, 1996) and has been shown to be one of the most sensitive hardwoods to atmospheric ozone in terms of development of visible foliar injury

* Corresponding Author: Myoung-Hui Yun (giniani9@rda.go.kr) 
(Neaufeld et al., 1995). Palisade cells in the leaf mesophyll are particularly sensitive to ozone injury and the collapse of individual cells or groups of palisade cells produces visible symptoms on the leaf surface (Fredericksen, 1996). Older leaves are more severely affected with advancing symptoms of premature senescence and defoliation (Skelly et al., 1998).

Genetic variations in sensitivity to ozone have been documented for several broad- leaved forest tree species. Reference showed that visible foliar injury among individual black cherry seedlings differed considerably. For example, the degree of visible foliar injury depended on sizes and ages of black cherry trees, suggesting the existence of sensitive and tolerant genotypes (Kolb et al., 1997; Fredericksen, 1996).

It is challenging to assess direct and indirect effects of ozone under natural environmental conditions due to the diversity of environmental factors that affect exposure-response relationship (Schaub et al., 2005). The present study was designed to determine the physiological processes that may cause the differences in foliar injury and growth response between sensitive and tolerant black cherry when exposed to ambient ozone concentrations under natural environment conditions. The main objectives were 1) to compare visible foliar injury and leaf gas exchange of black cherry with different sensitivities and 2) to better understand physiological mechanisms that may explain different sensitivity in foliar injury and growth response to ozone between genotypes.

\section{Materials and Method}

\subsection{Experimental site and design}

This study was conducted for three consecutive years, 2000, 2001, and 2002 during the growing season from May to September. The site was selected in the vicinity of Air Quality Monitoring Station located at Horton Research center in Giles County, Virginia, USA. A TECO ozone analyzer was used to measure ambient ozone concentrations. Weather variables including wind speed, wind direction, solar radiation, temperature, relative humidity $(\mathrm{RH})$, and rainfall were monitored at the station. Two groups of black cherry (Prunus Serotina Ehl.) with contrasting sensitivities were selected on site. The sensitivity was determined as symptomatic foliar injury, occurring as upper leaf flecking and dead tissue, during the previous summer. Three trees were selected to represent two sensitivity classes, sensitive and tolerant, respectively.

\subsection{Gas Exchange}

Gas exchange analysis was performed on the $3^{\text {rd }}$ basal leaf every month from May to September each year. Gas exchange analysis was conducted with a LiCor 6400 potable photosynthesis system (Li-Cor Inc., Lincoln, NE). Net photosynthetic rate under saturating light conditions $\left(\mathrm{Pn}_{\mathrm{MAX}}, \mu \mathrm{mol} \mathrm{CO}_{2} \mathrm{~m}^{-2} \mathrm{~s}^{-1}\right.$ at a light intensity of $900 \mu \mathrm{mol}$ quanta $\mathrm{m}^{-2} \mathrm{~s}^{-1} \mathrm{PAR}$ and $350 \mathrm{ppm}$ $\mathrm{CO}_{2}$ ) and stomatal conductance $\left(\mathrm{g}_{\mathrm{s}}, \mathrm{mol} \mathrm{H}_{2} \mathrm{O} \mathrm{m}^{-2} \mathrm{~s}^{-1}\right.$ ) were determined monthly from May to September on the $3^{\text {rd }}$ leaf position each year. Assimilation-Irradiance response curves (A-I) were obtained by measuring assimilation at $350 \mathrm{ppm} \mathrm{CO}_{2}$ concentration and irradiance ranging from 0 to $1200 \mu \mathrm{mol} \mathrm{m} \mathrm{m}^{-2} \mathrm{~s}^{-1}$ PAR monthly from May to September during the growing season. From the initial slope of A-I curve, the apparent quantum efficiency for net $\mathrm{CO}_{2}$ assimilation $\left(\mathrm{CO}_{2}\right)$ was determined. Assimilation - $\mathrm{CO}_{2}$ response curves were also generated at maximum light condition of 1100 $\mu \mathrm{mol} \mathrm{m} \mathrm{m}^{-2} \mathrm{~s}^{-1} \mathrm{PAR}$ and $\mathrm{CO}_{2}$ concentrations ranging from 0 to $1600 \mathrm{ppm}$.

\subsection{Visible foliar injury}

Visible injury was evaluated at two week intervals beginning in mid-May until the end of the season in mid-September each year. Leaf positions two through six in sensitive trees were examined. The percentage of visible injury of total leaf area was assessed on the upper leaf surface.

Leaf discs were used to determine total chlorophyll concentrations. Extraction was performed using pure DMSO solvent. Concentrations of chlorophyll $a$ and $b$ were determined spectrophotometrically at wavelengths of 663 and 645, respectively, according to Barnes et al. (1992) and related to the fresh weight of the leaves. Total chlorophyll concentrations were quantified and compared between sensitive and tolerant black cherry on the $3^{\text {rd }}$ leaves during the growing season, June to August. In September from sensitive trees, the relationship between total chlorophyll concentrations and percentage leaf injury was evaluated.

\subsection{Data analysis}

Two branches per tree and three trees per sensitivity class (i.e., sensitive and tolerant) were chosen on site. Each tree was designated as an experimental unit and each branch represented a pseudoreplicate. Statistical 
analysis of the data was performed with the Statistical Analysis System (SAS, Inc., NC, USA). Photosynthetic data as well as chlorophyll fluorescence data were analyzed by analysis of variance with ozone sensitivity as class variable. Statistical significance was designated at the $\mathrm{P} \leq 0.05$ probability level by a single asterisk and the $\mathrm{P} \leq 0.01$ level by two asterisks

\section{Results}

\subsection{Ozone exposure}

Black cherry trees were exposed to ambient ozone for 7 hours (from 09:00 to 16:00 hrs). On average, the concentration of ambient ozone was 51,51 , and $53 \mathrm{ppb}$ in 2000, 2001, and 2002, respectively. One-hour peak value of ambient ozone was higher in 2002 compared to those in 2000 and 2001 (Table 1). The highest onehour peak in 2000 and 2001 were recorded in June at 90 and $95 \mathrm{ppb}$, respectively. The highest one-hour peak in 2002 was recorded in July at $121 \mathrm{ppb}$ (Fig. 1). The seasonal SUM00 and SUM40 ozone values were higher in 2002 compared to 2000 and 2001(Table 1, Fig. 2).

\subsection{Physiological gas exchange}

For three growing seasons of investigation, photosynthetic activities differed between sensitivity classes in black cherry. The ambient ozone concentrations were high enough to induce the reductions of photosynthetic activity in sensitive class compared to tolerant class. The substantial reductions of $\mathrm{Pn}_{\mathrm{MAX}}$ and $\Phi \mathrm{CO}_{2}$ in sensitive class were observed throughout the experimental seasons for the three years. Such reductions were associated with seasonal cumulative ambient ozone expo-

Table 1. Seasonal means of atmospheric ambient $\mathrm{O}_{3}$ concentrations (ppb) and seasonal cumulative $\mathrm{O}_{3}$ concentrations (ppm h) at Horton research center in Giles County, VA, for three consecutive years from 2000 to 2002. Values are means \pm s.d.

\begin{tabular}{lccc}
\hline \hline & 2000 & 2001 & 2002 \\
\hline 7-h means & $51 \pm 13$ & $51 \pm 12$ & $53 \pm 13$ \\
12-h means & $51 \pm 12$ & $51 \pm 11$ & $53 \pm 13$ \\
Peak means & $58 \pm 13$ & $62 \pm 12$ & $66 \pm 16$ \\
Seasonal peak & 90 & 95 & 121 \\
SUM40 (ppm h) & NA & 67.46 & 75.77 \\
SUM00 (ppm h) & 80.47 & 81.38 & 85.02 \\
\hline
\end{tabular}

*NA: not available sure (SUM00). For example, $\mathrm{R}^{2}$ value for $\mathrm{Pn}_{\mathrm{MAX}}$ and $\Phi \mathrm{CO}_{2}$ were 0.80 and 0.82 , respectively. The values of $\mathrm{Pn}_{\mathrm{MAX}}$ and $\Phi_{\mathrm{CO}}$ for sensitive class increased at first.
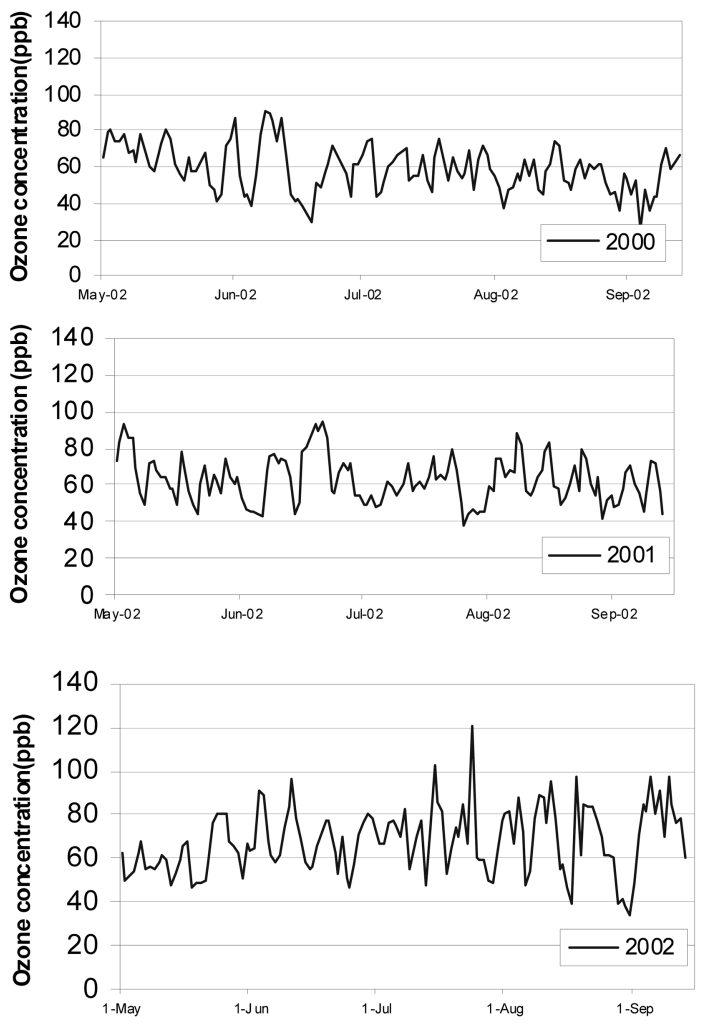

Fig. 1. Daily peaks of atmospheric ambient ozone concentration (ppb) at the Horton Research Center, Giles County, $\mathrm{VA}$, during the growing season of three consecutive years from 2000 to 2002 .

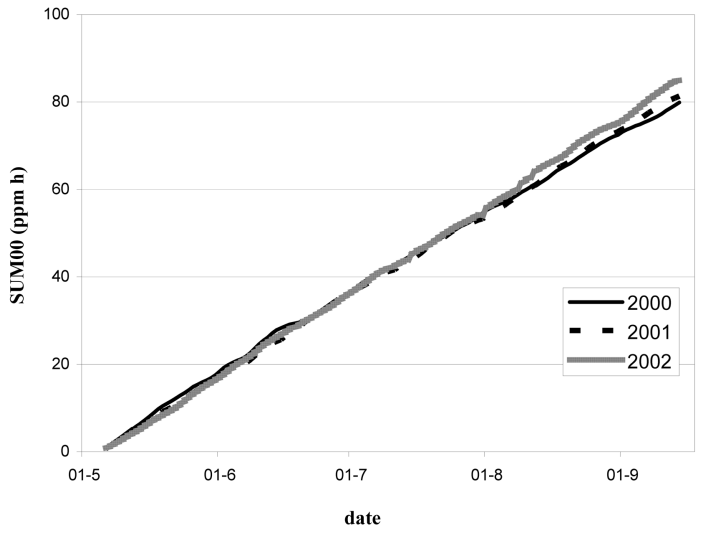

Fig. 2. Seasonal cumulative $\mathrm{O}_{3}$ concentrations (SUM00, ppm h) for three years from 2000 to 2002 in Giles County, VA. 


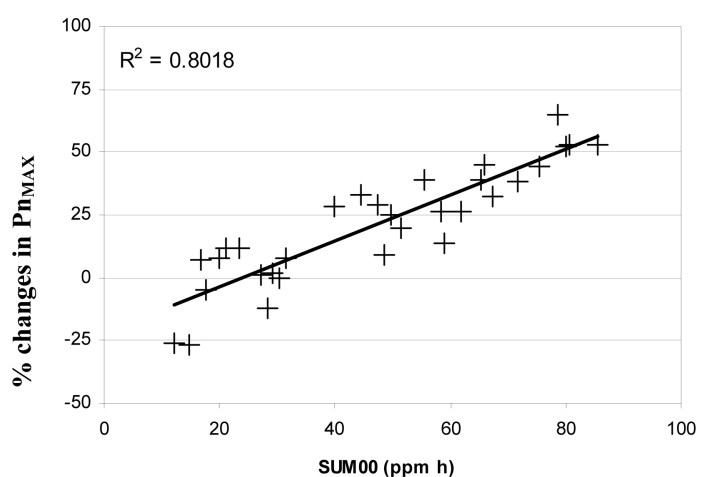

(A)

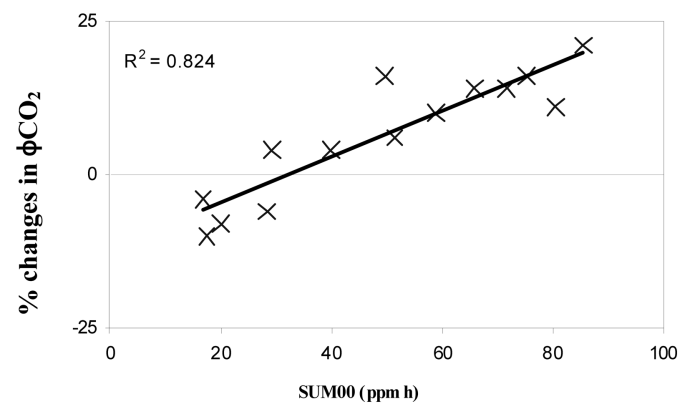

(B)

Fig. 3. Percent changes in (A) $\mathrm{Pn}_{\mathrm{MAX}}$ (maximum net photosynthetic rates, $\mu \mathrm{mol} \mathrm{CO} \mathrm{m}^{-2} \mathrm{~s}^{-1}$ at $\left.900 \mu \mathrm{mol} \mathrm{CO} \mathrm{Cm}^{-2} \mathrm{~s}^{-1}\right)$ and (B) apparent quantum yield for carbon reduction $\left(\mathrm{CO}_{2}\right.$, $\mu \mathrm{mol} \mathrm{CO}_{2} \mu \mathrm{mol}$ quanta $^{-1}$ ) in sensitive black cherry compared to tolerant black cherry related to cumulative $\mathrm{O}_{3}$ concentration ( $\mathrm{ppm} \mathrm{h}$ ). Data collected during the growing seasons from 2000 to 2002.

As SUM00 increased throughout the experimental growing seasons, $\mathrm{Pn}_{\mathrm{MAX}}$ and $\Phi \mathrm{CO}_{2}$ for sensitive class decreased (Fig. 3). This implies that, in the beginning, sensitive class had greater photosynthetic activities than tolerant class. However, as seasonal ambient cumulative ozone exposures increased, $\mathrm{Pn}_{\mathrm{MAX}}$ and $\Phi \mathrm{CO}_{2}$ for tolerant class were relatively consistent.

Gas exchanges measured on the $3^{\text {rd }}$ basal leaf from May to September each year are summarized in Table 2 for $2000 . \mathrm{Pn}_{\text {MAX }}$ was significantly higher in sensitive black cherry $\left(9.26 \mu \mathrm{mol} \mathrm{CO} \mathrm{CO}^{-2} \mathrm{~s}^{-1}\right)$ than in tolerant black cherry $\left(7.42 \mu \mathrm{mol} \mathrm{CO} \mathrm{CO}_{2} \mathrm{~m}^{-2} \mathrm{~s}^{-1}\right)$ at the beginning of the experimental season (e.g., May). Stomatal conductance $\left(\mathrm{g}_{\mathrm{s}} ; \mathrm{mol} \mathrm{H}_{2} \mathrm{O} \mathrm{m} \mathrm{m}^{-2} \mathrm{~s}^{-1}\right)$ was also significantly higher in sensitive black cherry $\left(0.17 \mathrm{~mol} \mathrm{H}_{2} \mathrm{O} \mathrm{m}^{-2} \mathrm{~s}^{-1}\right)$ compared to tolerant black cherry $\left(0.10 \mathrm{~mol} \mathrm{H}_{2} \mathrm{O} \mathrm{m}^{-2}\right.$ $\mathrm{s}^{-1}$ ) in May. In June, $\mathrm{Pn}_{\mathrm{MAX}}$ in both sensitive and tolerant black cherry were similar at 11.27 and $10.85 \mu \mathrm{mol}$ $\mathrm{CO}_{2} \mathrm{~m}^{-2} \mathrm{~s}^{-1}$, respectively. From June to September, stomatal conductance was not significantly different between sensitive and tolerant classes. However, $\mathrm{Pn}_{\mathrm{MAX}}$ started to decline in sensitive black cherry in July and was significantly reduced by $60 \%$ compared to tolerant black cherry in September. $\mathrm{Pn}_{\mathrm{MAX}}$ in tolerant black cherry remained relatively high at $9.77 \mu \mathrm{mol}$ $\mathrm{CO}_{2} \mathrm{~m}^{-2} \mathrm{~s}^{-1}$ until August, and then declined slightly as leaves naturally senesced in September.

In May, values of $\Phi \mathrm{CO}_{2}$ were significantly higher in sensitive black cherry compared to tolerant black cherry corresponding to $\mathrm{Pn}_{\mathrm{MAX}}$ and stomatal conductance. The values of $\Phi \mathrm{CO}_{2}$ reduced significantly in sensitive black cherry compared to tolerant black cherry in September. The values of $\mathrm{Pn}_{\mathrm{MAX}}$ and $\Phi \mathrm{CO}_{2}$ for tolerant black cherry declined slightly as leaves naturally senescensed.

During the experimental season, A-I response curves of black cherry were generated monthly and compared between sensitive and tolerant black cherry (data shown in Fig. 4 for 2002). Net $\mathrm{CO}_{2}$ assimilation rates $\left(\mathrm{Pn} ; \mu \mathrm{mol} \mathrm{CO} \mathrm{CO}^{-2} \mathrm{~s}^{-1}\right.$ ) increased as irradiance increased in both sensitive and tolerant black cherry (Fig. 4). In

Table 2. Maximum net photosynthetic rate $\left(\mathrm{Pn}_{\mathrm{MAX}}, \mu \mathrm{mol} \mathrm{CO} \mathrm{m}^{-2} \mathrm{~s}^{-1}\right.$ at $\left.900 \mu \mathrm{mol} \mathrm{CO} \mathrm{m}^{-2} \mathrm{~s}^{-1}\right)$ stomatal conductance $\left(\mathrm{g}_{\mathrm{s}}, \mathrm{mol} \mathrm{H} \mathrm{H}_{2} \mathrm{O} \mathrm{m}^{-2} \mathrm{~s}^{-1}\right)$, internal $\mathrm{CO}_{2}$ concentration $\left(\mathrm{C}_{\mathrm{i}}, \mathrm{ppm}\right)$ and apparent quantum yield for $\mathrm{CO}_{2}$ assimilation $\left(\mathrm{CO}_{2}, \mu \mathrm{mol} \mathrm{CO} 2 \mu \mathrm{mol}\right.$ quanta $\left.{ }^{-1}\right)$ on the $3^{\text {rd }}$ basal leaf of sensitive and tolerant black cherry during the growing season of 2000. Values are mean \pm s.d. Asterisks indicate the significant differences between cultivars. * at $\mathrm{P}<0.05$ and $* *$ at $\mathrm{P}<0.01$

\begin{tabular}{|c|c|c|c|c|c|c|c|c|c|c|}
\hline & \multicolumn{2}{|c|}{ May } & \multicolumn{2}{|c|}{ June } & \multicolumn{2}{|c|}{ July } & \multicolumn{2}{|c|}{ August } & \multicolumn{2}{|c|}{ September } \\
\hline & Sensitive & Tolerant & Sensitive & Tolerant & Sensitive & Tole & Sensitive & Tole & Sensitive & Tolerant \\
\hline $\mathrm{Pn}_{\max }$ & $9.16 \pm 0.67$ & $7.42 \pm 0.42 * *$ & $11.27 \pm 0.94$ & $10.85 \pm 1.50$ & $8.93 \pm 0.25$ & $9.81 \pm 0.42$ & $7.26 \pm 0.93$ & $9.77 \pm 0.93 * *$ & $2.85 \pm 0.67$ & $8.07 \pm 0.77 * *$ \\
\hline $\mathrm{g}_{\mathrm{s}}$ & $0.17 \pm 0.02$ & $0.10 \pm 0.01^{* *}$ & $0.30 \pm 0.02$ & $0.26 \pm 0.04$ & $0.21 \pm 0.02$ & $0.16 \pm 0.06$ & $0.21 \pm 0.04$ & $0.22 \pm 0.01$ & $0.22 \pm 0.04$ & $0.21 \pm 0.02$ \\
\hline $\mathrm{C}_{\mathrm{i}}$ & $234 \pm 7.2$ & $206 \pm 9.1 * *$ & $259 \pm 4.2$ & $254 \pm 5.1$ & $256 \pm 6.1$ & $200 \pm 10.8$ & $298 \pm 9.5$ & $278 \pm 5.5^{*}$ & $308 \pm 10.0$ & $273 \pm 4.0 * *$ \\
\hline $\mathrm{CO}_{2}$ & $0.050 \pm 0.002$ & $0.046 \pm 0.003$ & - & _ & $0.047 \pm 0.001$ & $0.048 \pm 0.002$ & $0.042 \pm 0.002$ & $0.049 \pm 0.002 *$ & 0.031 & $0.039 \pm 0.002 * *$ \\
\hline
\end{tabular}

- : data not available 

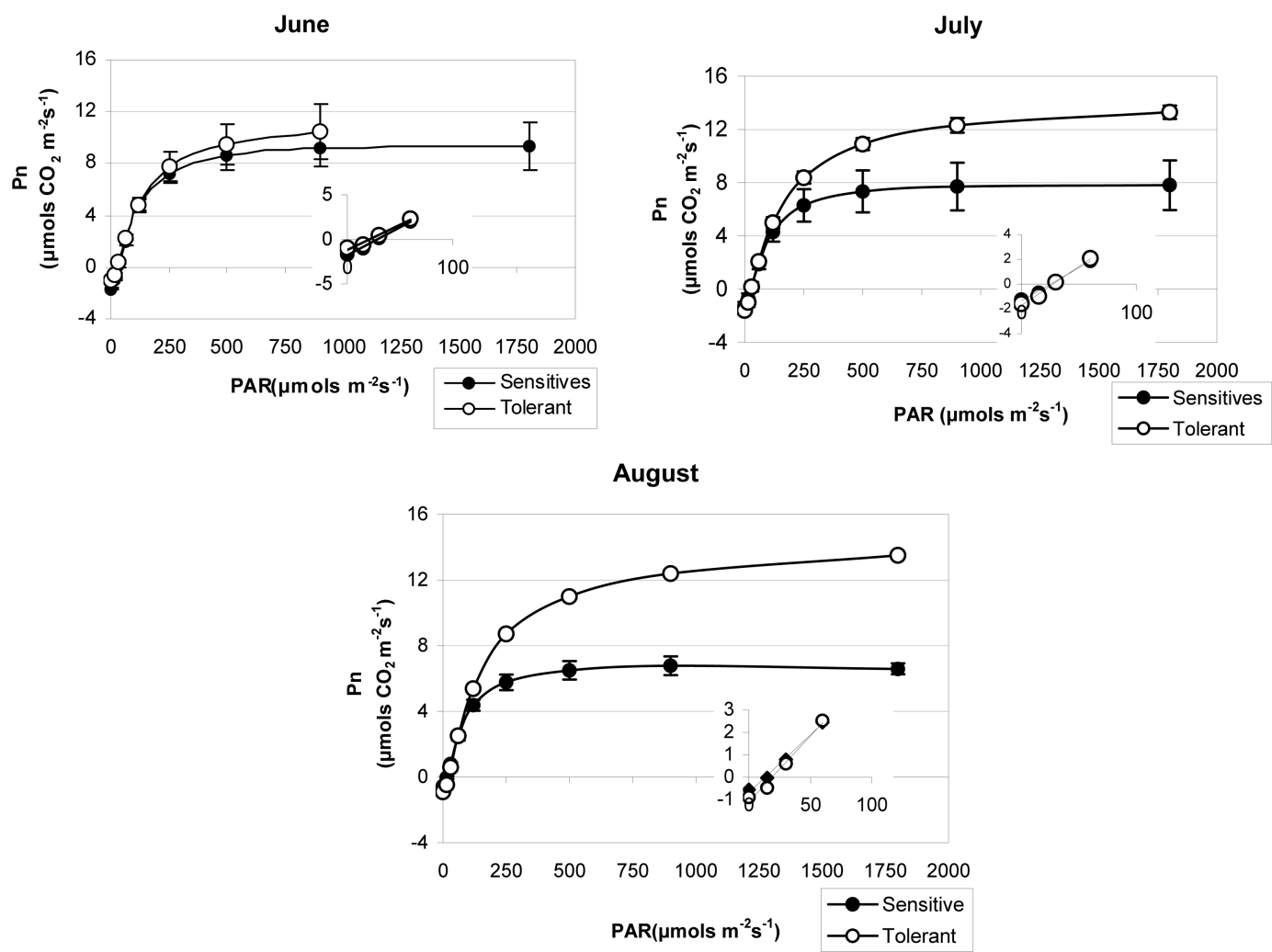

Fig. 4. Net assimilation rate (Pn; $\left.\mathrm{mol} \mathrm{CO} \mathrm{Cm}^{-2} \mathrm{~s}^{-1}\right)$-Irradiance (PAR; $\mathrm{mol} \mathrm{m}^{-2} \mathrm{~s}^{-1}$ ) response curves on the $3^{\text {rd }}$ leaf of sensitive (closed circles) and tolerant (open circles) in black cherry during the growing season of 2002. Inserts are the initial slopes of the A-I response curves. Bars represent \pm one standard deviation of the means and, where not apparent, are contained within symbols.

June, Pn values for sensitive and tolerant black cherry were not different significantly under all light conditions. From July, however, Pn under light conditions higher than $150 \mu \mathrm{mol} \mathrm{m} \mathrm{m}^{-2} \mathrm{~s}^{-1}$ PAR reduced significantly in sensitive black cherry compared to tolerant black cherry.

Net $\mathrm{CO}_{2}$ assimilation rates in response to various $\mathrm{CO}_{2}$ concentrations were measured during the experimental season in 2002. A- $\mathrm{CO}_{2}$ response curves were generated and compared between sensitive and tolerant black cherry (Fig. 5). In 2002, Pn increased as $\mathrm{CO}_{2}$ concentrations increased (Fig. 5). In June, Pn, at lower $\mathrm{CO}_{2}$ concentration than ambient conditions of 350 ppm, was not significantly different in both sensitive and tolerant black cherry. However, $\mathrm{Pn}$, at higher $\mathrm{CO}_{2}$ conditions than $350 \mathrm{ppm}$, was significantly reduced in sensitive black cherry compared to tolerant black cherry. Under the doubled ambient $\mathrm{CO}_{2}$ conditions (i.e., $>800 \mathrm{ppm}$ ), the reduction of $\mathrm{Pn}$ in sensitive black cherry was $20 \%$ compared to that of tolerant black cherry. From July, Pn, at ambient $\mathrm{CO}_{2}$ conditions of $350 \mathrm{ppm}$, was reduced in sensitive black cherry compared tolerant black cherry. By August, at even lower $\mathrm{CO}_{2}$ conditions, Pn was significantly reduced in sensitive black cherry compared to tolerant black cherry. In August, reductions of $\mathrm{Pn}$ in sensitive black cherry compared to tolerant black cherry were getting greater as $\mathrm{CO}_{2}$ concentrations increased.

The values of $\Phi_{\mathrm{CE}}$ for both sensitive and tolerant black cherry were not significantly different in June. However, from July, reductions of $\Phi_{\mathrm{CE}}$ in sensitive black cherry compared to tolerant black cherry were significant. By August, reduction of $\Phi_{\mathrm{CE}}$ in sensitive black cherry was more than $40 \%$ compared to tolerant black cherry (data not shown).

\subsection{Visible foliar injury}

From late July to early August, visible foliar injury 

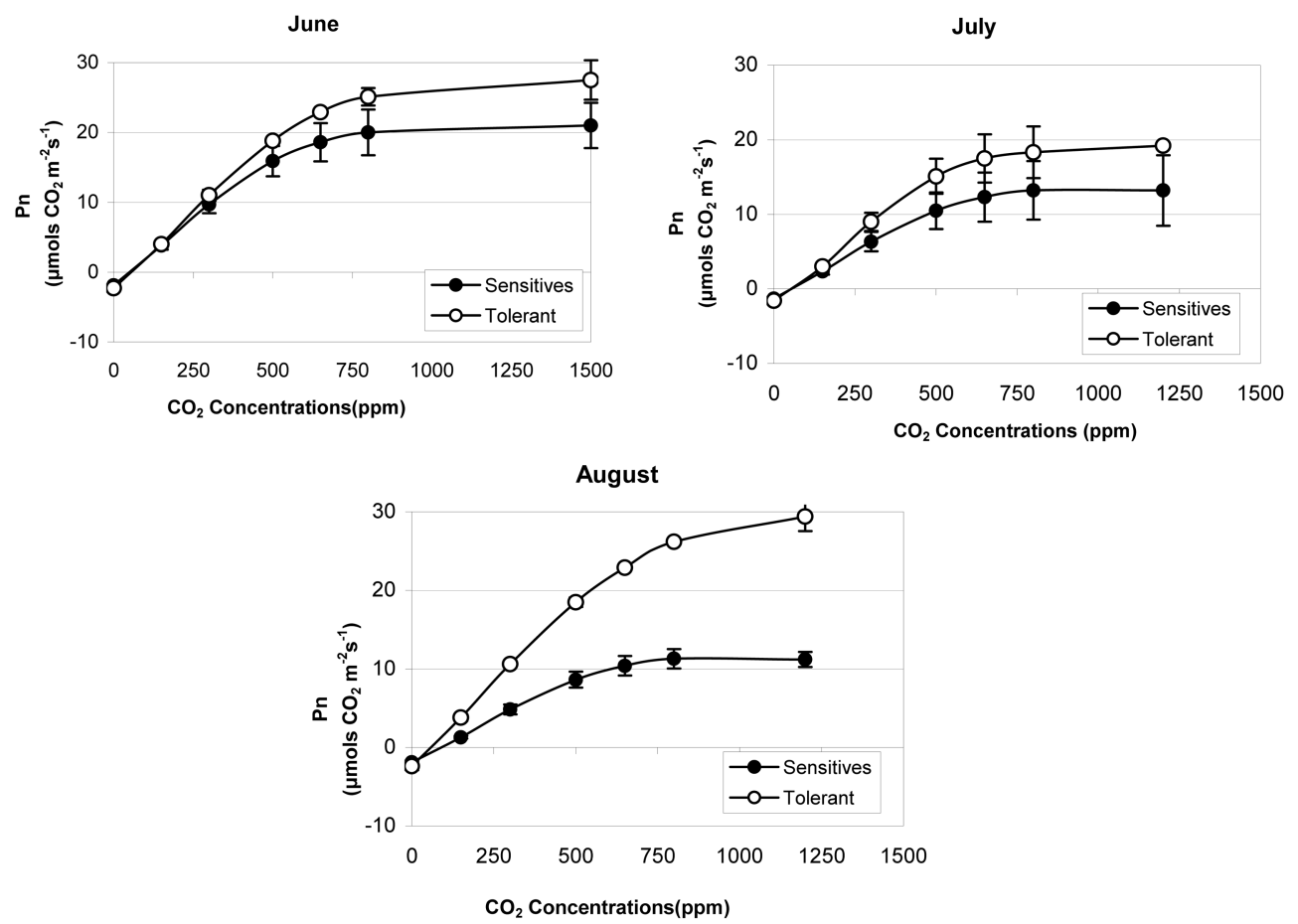

Fig. 5. Net assimilation ( $\mathrm{Pn} ; \mathrm{mol} \mathrm{CO} \mathrm{m}^{-2} \mathrm{~s}^{-1}$ ) - $\mathrm{CO}_{2}$ concentrations (ppm) response curves (at $1100 \mu \mathrm{mol} \mathrm{m} \mathrm{m}^{-2} \mathrm{~s}^{-1} \mathrm{PAR}$ ) on the $3^{\text {rd }}$ leaf of sensitive (closed circles) and tolerant (open circles) black cherry during the growing season of 2002. Bars represent \pm one standard deviation of means and, where not apparent, are contained within symbols.

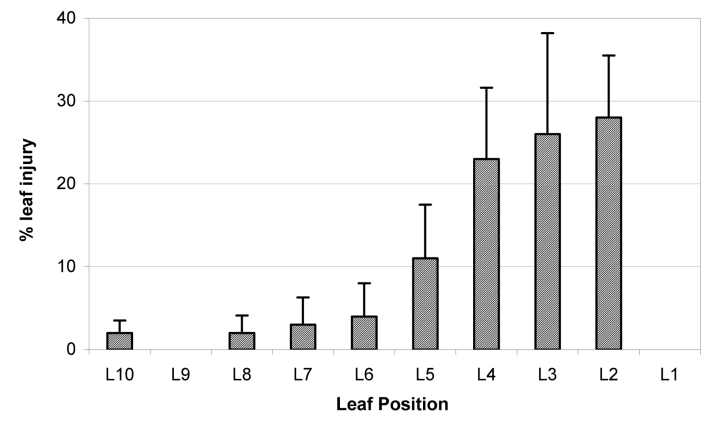

Fig. 6. Percent visible foliar injury of total leaf area estimated on the different leaf positions of sensitive black cherry in September 2001. Leaf position 10 (L10) is the youngest leaf estimated. Error bars represent standard deviations of the means.

became apparent on leaves of sensitive black cherry. Towards the end of growing season in September, most leaves showed visible injury in sensitive black cherry. The symptoms appeared as brown spots on the upper surface of leaves, which is typical foliar injury induced by ozone in black cherry. The estimated foliar injury was more severe in older leaves with 30 to $35 \%$ of total leaf area

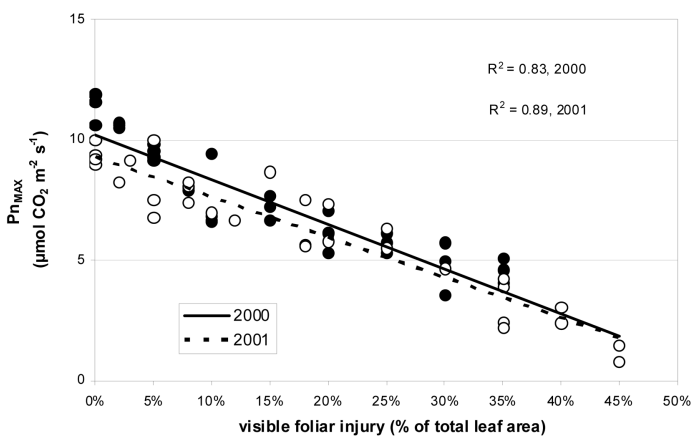

Fig. 7. $\mathrm{Pn}_{\mathrm{MAX}}$ (maximum net photosynthetic rates, $\mu \mathrm{mol}$ $\mathrm{CO}_{2} \mathrm{~m}^{-2} \mathrm{~s}^{-1}$ at saturated light condition of $900 \mu \mathrm{mol} \mathrm{m}^{-2} \mathrm{~s}^{-1}$ ) related to percent visible foliar injury of sensitive black cherry in consecutive 2 years, 2000( solid line and closed circles) and 2001 (dotted line and open circles).

than in younger leaves with 0 to $5 \%$ (Fig. 6). This visible foliar injury was well correlated with photosynthetic activity and chlorophyll contents. $\mathrm{Pn}_{\mathrm{MAX}}$ was related inversely to percent visible foliar injury with an $\mathrm{R}^{2}$ value of 0.83 in 2000 and 0.89 in 2001 (Fig. 7). Chlorophyll contents were also related inversely to percent visible foliar injury with an $\mathrm{R}^{2}$ value of 0.95 (Fig. 8). 


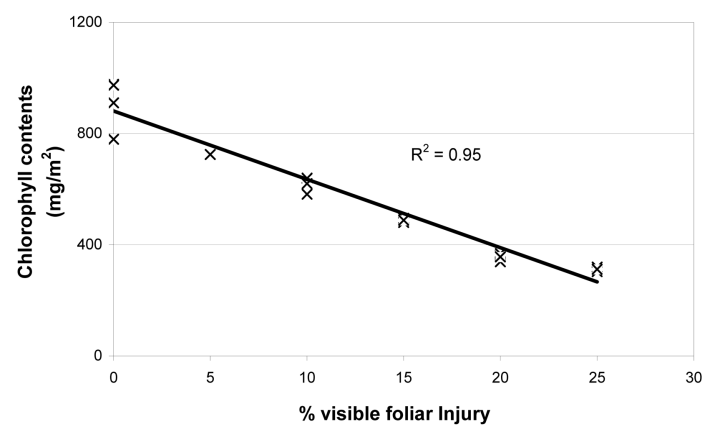

Fig. 8. Chlorophyll contents $\left(\mathrm{mg} \mathrm{m}^{-2}\right)$ related to percent visible foliar injury of total leaf area in sensitive black cherry in September 2002. Each sample point has three samples.

\section{Discussion}

In our study, level of exposure to ambient ozone in terms of concentrations and duration was high enough to cause visible foliar injury and to disrupt physiological activity only in sensitive black cherry. Our results were similar to those reported by Schaub et al. (2005). The seasonal 7-h and 12-h ambient ozone concentrations averaged 40-50 ppb (Table 1) and episodic peaks reached 90 to $120 \mathrm{ppb}$ (Fig. 1), which typically occurs during the summer in Mid-Atlantic States (Skelly, 2000 and Schaub, 2003)

Our results showed that visible foliar injury of sensitive black cherry resulted from greater stomatal conductance and consequently greater ozone uptake than those of tolerant black cherry (Table 2). High ozone uptake with greater stomatal conductance in sensitive black cherry seedlings has been linked to greater ozone injury than tolerant black cherry seedlings (Kouterick et al. 2000). Our results confirmed that foliar injury was correlated with stomatal conductance in black cherry. For example, Ferdinad et al. (2000) reported that stomatal density of sensitive black cherry seedlings was greater than that of tolerant ones because the sensitive seedlings had greater potential of stomatal conductance than tolerant ones. Even though ozone tolerant mature black cherry showed greater leaf area, stomatal density was still significantly greater for ozone sensitive black cherry.

The response to ozone is underestimated, however, if sensitivity emphasizes only the differences in stomatal conductance (Schaub et al., 2005). Not only stomatal density but other internal morphological leaf characteristic may play an important role in response to ozone of sensitive black cherry. Fredericksen et al. (1995) reported thinner leaves and a lower palisade/spongy mesophyll thickness ratio in sensitive black cherry than tolerant black cherry. According to Ferdinand et al. (2000), leaves of R-12, ozone-sensitive seedlings, displayed greater spongy mesophyll with greater intercellular air space and thinner palisade mesophyll than MO-7, ozone-tolerant seedlings. These morphological characteristics in sensitive black cherry would provide less mesophyll resistance to ozone ingress to the palisade mesophyll and may lead dead palisade mesophyll cells and visible foliar injury. Evans et al. (1996) also supported that certain leaf morphological characteristics such as stomatal density and intercellular air space may lead ozone ingress into leaves and internal diffusivity among ozone target cells, such as palisade mesophyll cells. Although direct morphological characteristics have not been measured, a clear linear relationship between chlorophyll contents and foliar injury were observed in sensitive black cherry with $\mathrm{R}^{2}$ value of 0.95 in this study (Fig. 8). As chlorophyll contents decreased, greater visible foliar injury was observed.

Kouterick et al. (2000) reported that the differences in ozone uptake and visible foliar injury between families did not correspond with family differences in photosynthetic activity to ozone exposure. They observed that the relative ozone sensitive family R-12 had more visible foliar injury as well as higher Pn than relative ozone tolerant family MO-7 throughout the growing season. In addition, all measurements of Pn were 12 to $17 \mu \mathrm{mol} \mathrm{CO} \mathrm{CO}_{2} \mathrm{~m}^{-2}$ for sensitive family $\mathrm{R}-12$ and 10 to $16 \mu \mathrm{mol} \mathrm{CO} \mathrm{CO}^{-2} \mathrm{~s}^{-1}$ for tolerant family MO-7 under $600 \mu \mathrm{mol} \mathrm{m} \mathrm{m}^{-2} \mathrm{~s}^{-1}$ light conditions regardless to seasonal cumulative ozone concentration. However, they measured Pn of newly expanded young leaf throughout the growing season and cumulative effect of ozone was not considered. Such young leaves would have higher Pn and yet would not be severely affected by ozone. Our results clearly showed that reductions of Pn in sensitive black cherry compared to tolerant black cherry were correlated with seasonal cumulative ozone concentrations (Fig. 3).

Greater foliar injury in the older leaves was observed in sensitive black cherry at the end of growing season due to a longer duration of ozone exposure than younger leaves produced later in the growing season (Fig. 6). Older leaves also showed more severe injury in $\mathrm{Pn}_{\mathrm{MAX}}$ than younger leaves in sensitive black cherry (data not shown). Visible foliar injury was well correlated to photosynthetic activity in this study. The per- 
cent leaf injury of total leaf area was negatively related to $\mathrm{Pn}_{\mathrm{MAX}}$ in sensitive black cherry with $\mathrm{R}^{2}$ value of 0.83 and 0.89 in 2000 and 2001, respectively (Fig. 7). Our results agree with other studies on other ozone sensitive trees and crops, which showed a clear inverse relationship between visible foliar injury and photosynthetic activity (Davis and Skelly, 1992; Flagler, 1994). Our results indicated that visible foliar injury was related to photosynthetic activity between black cherry families. Therefore, visible foliar injury could be used as a simple measure to study ozone impacts on black cherry in terms of genetic difference.

With limited access to biochemical mechanisms such as direct measure of production and activation of RUBISCO, carboxylation efficiency was determined from the assimilation- $\mathrm{CO}_{2}$ response curves during the growing season in 2002 and compared between sensitive and tolerant black cherry (Fig. 5). Carboxylation efficiency in sensitive black cherry was reduced in July with other photosynthetic activity. When carbon is not a limiting factor under saturating $\mathrm{CO}_{2}$ conditions, however, the maximum rate of electron transport used in the regeneration of RUBP was reduced in sensitive black cherry at first.

This study demonstrated the different genetic responses of black cherry to ambient ozone concentrations under the natural environment conditions. The genotypic differences in response to ozone have been clearly observed. Further researches in genetic variations of ozone sensitivity among black cherry should include examinations of biochemical analysis such as anti-oxidant production and RUBISCO activity levels which differ in sensitivity to foliar ozone injury.

\section{적 요}

오존은 식물에 가장 큰 피해를 주는 대기 오염원 중 하나로 알려져 있으며, 현재 대기 중 오존 농도만으로 도 민감한 종에서는 피해가 관찰된다. 기공을 통해 유 입된 실제 오존량이 식물의 잎에 상당한 피해를 입히며, 광합성률의 저하를 일으키는 것으로 알려져 있다. 식물 의 오존에 대한 반응은 식물의 생리적 연령과 민감성 에 따라 다양하며, 잎의 성숙과 밀접하게 연관되어 있 다. 가장 최근에 성숙한 잎이 이미 성숙한 잎들이나 빠르게 성장하는 어린 잎들과 비교해 보았을 때 오존 에 가장 예민한 것으로 알려져 있다. Black Cherry (Prunus serotina)는 경제적, 생태적으로 중요한 수종중 의 하나이다. 또한 오존에 민감한 수종중의 하나이며,
대기 중 오존 농도에 의해 피해를 보여, 오존의 생물 지표로 이용되기도 한다. 상이한 오존 민감성은 유전적 차이에 기인하는 것으로 알려져 있으며, 이 점으로 인 해 대기 중 오존 농도가 식물의 광합성 및 PSII 기능 에 미치는 영향을 연구하기에 이상적인 수종으로 여겨 진다. 이에 본 연구는 3년간 버지니아 주 Giles County 에 위치해 있는Horton 연구센터 실험 숲에서, Black Cherry 중 상이한 두 민감성을 보이는 품종을 이용하여 대기 중 오존 농도가 민감한 품종과 저항성 을 지닌 품종에 미치는 영향을 연구하였다. 대기 중 오존에 노출된 채로 식물의 생장이 가장 빠른 성장기 를 거친 결과, 대기 중 오존에 의해 민감한 품종은, 가시적인 피해와 함께 최대 순 광합성이나 탄소 동화 에 대한 양자 수득율이 크게 감소되었으나 저항성을 지닌 품종은 가시피해의 부재와 함께 소폭의 최대 순 광합성 및 양자 수득률의 피해가 관찰되었다. 오존에 민감한 품종에서 잎의 가시피해는 광합성 기능과 밀접 하게 연관되어 있으며, 잎의 생리적 연령이 늘어남에 따라 더욱 커지는 것으로 관찰되었다. 오존에 저항성이 있는 품종에서도 잎의 연령 증가에 따른 광합성 기능 의 저하가 관찰 되었으나, 가시피해는 관찰되지 않았다. 오존에 의한 총 광합성률의 감소는 오존에 민감한 품 종에서 더욱 현저하게 관찰되었다.

\section{REFERENCES}

Davis, D. D. and J. M. Skelly, 1992: Growth response of four species of eastern hardwood tree seedlings exposed to ozone, acidic precipitation, and sulfur dioxide. J. Air Waste Manage Assoc. 42, 309-311.

Evans, L. S., K. Albury, and N. Jennings, 1996: Relationships between anatomical characteristics and ozone sensitivity of leaves of several herbaceous dicotyledonous plant species at Great Smoky Mountains National Park. Environmental-and-Experimental-Botany 36, 413-420.

Ferdinand, J. A., T.S. Fredericksen, K. B. Kouterick, and J. M. Skelly, 2000: Leaf morphology and ozone sensitivity of two open pollinated genotypes of black cherry (Prunus Serotina) seedlings. Environmental Pollution 108, 297-302.

Flagler, R. B., J. E. Lock, and C. G. Elsik, 1994: Leaf-level and whole-plant gas exchange characteristics of shortleaf pine exposed to ozone and simulated acid rain. Tree Physiology 14, 361-374.

Fredericksen, T. S., B. J. Joyce, J. M. Skelly, K. C. Steiner, T. E. Kolb, K. B. Kouterick, J. E. Savage, and K. R. Snyder, 1995: Physiology, Morphology, and ozone uptake of leaves of black cherry seedlings, saplings, and canopy trees. Environmental Pollution 89, 273-283. 
Fredericksen, T. S., J. M. Skelly, K. C. Steiner, T. E. Kolb, K. B. Kouterick, 1996: Size-mediated foliar response to ozone in black cherry trees. Environmental P.zollution 91, 53-63.

Kolb, T. E., T. S. Fredericksen, K. C. Steiner, and J. M. Skelly, 1997: Issues in scaling tree size and age responses to ozone; a review. Environmental Pollution 98, 195-208.

Kouterick, K. B., J. M. Skelly, T. S. Fredericksen, K. C. Steiner, T. E. Kolb, and J. A. Ferdinand, 2000: Foliar injury, leaf gas exchange and biomass responses of black cherry (Prunus serotina Ehrh.) half-sibling families to ozone exposure. Environmental Polltuion 107, 117-126.

Neufeld, H. S., E. H. Lee, J. R. Renfro, W. D. Hacker, and B. H. Yu, 1995: Sensitivity of seedlings of black cherry (prunus serotina Ehrh.) to ozone in Great Smoky Mountains National Park I. Exposure-response curves for biomass. New Physiologist 130, 447-459.

Rebbeck, J., 1996: Chronic ozone effects on three northeastern hardwood species: growth and biomass. Can. J. For. Res. 26, 1788-1798.

Reich, P. B., 1987: Quantifying plant response to ozone: a unifying theory Tree Physiology 3, 63-91.

Samuleson, L. J., 1994: Ozone - exposure responses of black cherry and red maple seedlings. Environmental and Experimental Botany 34, 355-362.
Schaub, M., J. M. Skelly, K. C. Steiner, D. D. Davis, S. P. Pennypacker, J. Zhang, J. A. Ferdinand, J. E. Savage, and R. E. Stevenson, 2003 Physilogical and foliar injury responses of Prunus serotina, Fraxinus americana, and Acer rubrum seedlings to varying soil moisture and ozone. Environmental Pollution 124, 307-320.

Schaub, M., J. M. Skelly, J. W. Zhang, J. A. Ferdinand, J. E. Savage, R. E. Stevenson, D. D. Davis, K. C. Steiner, 2005: Physiological and foliar symptom response in the crowns of Prunus serotina, Faxinus americana and Acer rubrum canopy trees to ambient ozone under forest conditions. Environmental Pollution 133, 552-567.

Simini M., J. M. Skelly, D. D. Davis, J. E. Savage, and A. C. Comrie, 1992: Sensitivity of four hardwood species to ambient ozone in north central Pennsylvania. Can. J. of For. Res 22, 1789-1799.

Skelly, J. M., 2000: Tropospheric ozone and its importance to forests and natural plant communities of the northeastern united states. Northeastern naturalist 7 , 221-236.

Skelly, J. M., J. L. Innes, K. R. Snyder, J. E. Savage, C. Hog, and W. Landolt, 1998 Investigations of ozone induced injury in forests of southern Switzerland: field surveys and open-top chamber experiments. Chemosphere 35, 995-100. 